\title{
Impact of Job Design on Employee's Satisfaction Level in Pakistan
}

\author{
Muhammad Ali Hussain \\ School of Management \& Economics \\ University of Electronic Science \& Technology of China, Chengdu, \\ Sichuan, 610000, P. R. China \\ School of Business Management \\ NFC Institute of Engineering \& Fertilizer Research \\ (Affiliated with UET Lahore), Faisalabad, 38000, Pakistan \\ Muhammad Waleed Ayub Ghouri \\ School of Management \& Economics \\ University of Electronic Science \& Technology of China, \\ Chengdu, Sichuan, 610000, P. R. China \\ Muhammad Hassan \\ Department of Business Administration \\ Government College University Faisalabad, 38000, Pakistan \\ Tehmina Kanwal \\ School of Management \& Economics \\ University of Electronic Science \& Technology of China, \\ Chengdu, Sichuan, 610000, P. R. China \\ Mamoon Rashid \\ School of Management \& Economics \\ University of Electronic Science \& Technology of China, Chengdu, \\ Sichuan, 610000, P. R. China
}

\begin{abstract}
Employee's satisfaction in service organization was one of the major concern of every employer to enhance the growth of the organization. This research has analyzed the perspective of different employees of public and private universities. The study examined the behavior of employee's who were asked to fill the questionnaire. This research was exploratory in nature and the measurement tool used for this study is quantitative. The Likert and dichotomous scale were used in questionnaire format. Data has been collected through properly administered questionnaire. Total respondents were 100 . The research findings show that the independent variables motivation, feedback, job design, and healthy environment etc. have a significant impact on the employee's satisfaction. This research has an impact on all the small and medium scale organizations. There were some limitations due to a shortage of time and funds. That's why the large geographical area hasn't been covered. Through this research, the employees feel more comfortable in the organization and committed towards the betterment of the organization.
\end{abstract}

Keywords: Job design, Employee's satisfaction, motivation, and feedback etc. 


\section{INTRODUCTION}

Human capital is one of the most important roles in the organization as compared to other assets such as latest technology, land, and organization structure. In current era it's beneficial for the employers to design the job according to the nature of the employee's so, automatically get immense returns. As this research based on the universities professors faced different conflicts while performing the job. Human resource management never completes until it properly values the job design.

In a modern revolution, job design becomes the vital factor that got the attention of every employer belonging to any sector. But as this research conducted on the education sector because the growth opportunities in this sector gradually increase. The higher authority needs to worry about the factors that hinder the organization growth and take proper remedies against this. By implementing proper policies and regulations then output must be a phenomenon.

Put simply, "job design refers to the way tasks are combined to form complete jobs" (Robbins and Stuart-Kotze). Jobs must be designed and structured in such a way that they will increase employee's satisfaction. So, automatically the employer will see benefits because employees feel themselves to be the part of the organization (Bahram Alishiri, 2012).

The output of the employee depends on how the job contents, duties, and responsibilities are given to the employees according to their core competencies. Job satisfaction level depends on what extent the employees feel secure on the job. Moreover, the employee gets the proper exchange value in against of their performance in the organization.

Performance improvement has got the major attention in the education sector to increase organization growth and stability. Performance of the employees depending upon the nature of the work and the organization policies which directly relates to the productivity. The organization aims to get maximum productivity by projecting proper fit for the employees. By doing this the organization build a strong reputation in the market with positive word of mouth and committed to their vision.

In current evolution, the biggest challenge faced by the top executives is the most favorable design of job and work organization to meet conflicting demands. The remedy for this never helpful until you will design the job according to employee capabilities and their mindsets.

There are various factors which affect the employee satisfaction. In this research, some of these factors are motivation, healthy environment (relaxation of working hours, work under stress), intrinsic benefits (Pay, promotion), feedback (positive and negative both) and teamwork. Through these variables, we check the proper relationship between the job design and employee's satisfaction.

Properly designed and administered jobs have a positive influence on employee motivation and performance, which directly leads to improve individual and group organizational performance outcomes such as their membership (joining/leaving an organization), reliable role behavior (how well the worker does their job), and decision-making power (across the normal decisions) (Ugboro, 2006).

Work design refers to a continuum job nature and its contents include the internal and external factors in such a way that the tasks are coordinated and arranged, that guide people what to do in specific circumstances and how effectively they can do it. The concept has roots 
in psychological research and theories of work motivation to improve employee satisfaction and performance and therefore increase organizational productivity and efficiency (Campion, Mumford, Morgeson \& Nahrgang, 2005).

At last the organization doesn't ignore the factors that give value to the employee's core competencies (knowledge, skills, and abilities). As the education sector is playing a dominant role in the well-being of society and lead the country to the ladder of success. So, until the professors did not get the proper respect and benefits as they expected in against of their work, then gradually the employee's de-motivated and have negative intentions in the mind. The literate people is the valuable asset of Pakistan so, we must retain it at any cost.

The reason behind the employee leaving the organization just because they thought the opportunities here are not up to the mark and we waste our talent over there. In such circumstances, they prefer to switch the job and avail the golden opportunity in anywhere not just show the talent and earn a good name as well.

\section{Objectives of the study:}

The objectives of this study as follows:

a) To identify the factors that influence the employee's performance as a consequence of job design

b) To measure the relationship between job design and employee's satisfaction

c) Which factors have more value in the eyes of employee's

d) Provides remedies on those points that hinder organization growth

\section{Scope of study:}

This research applicable to all universities including private and public with context to Pakistan. Moreover, this research influences the other researchers in a positive way to consider such important sector while conducting research. The research findings helpful for the organization to take precautionary measures before the problem entered. This study generalized to all sectors to take proper steps for the organization.

\section{Methodology:}

The research is exploratory in nature and the researcher has used both primary and secondary sources of data for this study. The primary source involves the data collected through administered questionnaire and secondary resources through research articles, books, and journals etc.

The questionnaire format ranging from close-ended to open-ended. Moreover, for data analysis and interpretation, I get help from the SPSS (statistical package for social sciences) software. It gives more authentications and reduces errors of human calculations.

\section{LITERATURE REVIEW}

A job can be explained as the crew of similar looking jobs that alike in terms of work performed and committed to the goals of the organization for which purpose they hire, where a position is the "set of duties, tasks, activities, and elements able to be performed by a single worker" (Brannick, Levine, \&Morgeson, 2007, p. 7). Job design thus refers to the "content and structure of jobs that employees perform" (Oldham, 1996, p. 33).

Job design is considered to be the hot issue in human resource management. After all, designing work in such a way that employees achieve a great degree of power, get an identity, 
encourage in decision making so, the employee's job satisfaction gradually increases because of giving proper feedback and variety of tasks. (Hodgetts and Hegar, 2005)

Job satisfaction is defined as the degree to which people accept or reject their jobs and working environment (Spector, 1997). This definition proposed that job satisfaction is a worldwide phenomenon and depends on individual beliefs hold about their job. Most scholars recognize that job satisfaction is a global concept comprised of various features such as employee satisfaction with pay, supervisors, and co-worker's behavior and chances of promotion (Judge et al., 2001; Rainey, 2003)

Despite, a lot of controversies studies depict that job satisfaction both positive and negative facets. On the positive side job, satisfaction is highly correlated with organizational commitment, job involvement, motivation, organizational citizenship behaviors, feedback environment, and job performance (Adebakin et al., 2008; Anseel and Lievens, 2007; Brewer and Lee, 2005). And on the contrary related to turnover, absenteeism and perceived stress (Judge et al.,2001; Kreitner and Kinicki, 2001).

Andy and Mohammed (2006) found that employees satisfaction level decreasing in the period of December 1993 to June 1998. Their result shows that the customers demand more satisfaction from the organization at the expense of employees. There is an established body of knowledge supporting the idea that certain jobs and goal setting can enhance performance (Garg \& Rastogi, 2006).

Performance improvement in any organization is not predicting only through running an effective system but it also depends upon the human resource strategies related to recruitment and selection that result in retain a talented and motivated employee (Al-Ahmadi, 2009).

The dimensions of performance on which an employee is judged are known as the predetermined evaluation criteria through which we analyze the satisfaction level of every individual (Ivancevich, 1998). Opatha, (2002) proposed several precautionary measures were needed in order to reduce the chances of errors while performing the job. "In the view of Mathis and Jackson, (2003), the data or information which the managers receive on how well employees are performing their jobs can be of three different types as Trait-based information, Behavior-based information, Result-based information." Opatha, (2002) indicated that traitbased information depicts the outward character of the employee such as attitude, initiative or creativity. Behavior-based evaluations of job performance attention what type of features included in the job (Mathis \& Jackson, 2003). Results are outcomes produced by the employee. Result based information consider employee achievements in the specific time period. For jobs in which measurement is easy and obvious, a results-based approach works well (Opatha, 2002).

Job design characteristics highlight the fact that performing work has a prominent influence on role performance, however, the conflicts come under the umbrella of work design and their implementation phases. An organization's motive for reliable role behavior may be to increase in performing work efficiency versus satisfaction, a conflicting opposition to work design mindsets and principles (Campion, et al, 2005).

In fact, Mehta \& Shah, (2005) showed that in organizations where focus was on lean production (quality, efficiency, and responsiveness), employees struggling for the betterment without such factors task identity, power and it proposed that workers perform more efficiently because their personal traits is parallel to the organization values (Mehta \& Shah, 
2005). Job design features generally focused on designing the according to the individual's mindset and moreover, this can be generalized and applied to the pool of employees, certain job characteristics become detrimental to performance (Sinha \& Ven, 2005).

In this case, task identity and power become less value as compared to hierarchical authority and broadly defined tasks. Job dimensions, when implementing through proper channels that can complement an employee's inherent values and increasing satisfaction level towards the job.

Employee involvement is explained as a positive and develops their mind according to work and characterized by different aspects like potential, devoted and absorption etc. (Schaufeli, Bakker, and Salanova, 2006). Potential of any worker refers to put all the efforts in the work and cross the hurdles in a proper way. Devotion in the work refers to involve in the work with full passion and experiences new phases of life. Absorption is the last component of the employee involved in which the worker indulges in their work with enthusiasm and not cheat the original value of work (Schaufeli et al., 2006). Employee involvement has attracted considerable interest from researchers and practitioners because these directly impact on the employee's performance and organization growth (Christian, Garza and Slaughter,2011; Demerouti and Cropanzano, 2010; Harter, Schmidt, and Hayes, 2002).

"Job design is the process of putting together a range of tasks, duties, and responsibilities to create a composite for individuals to undertake in their work and to regard as their own. It is crucial: not only is it the basis of individual satisfaction and achievement at work, it is necessary to get the job done efficiently, economically, reliably and safely." (Torrington et al., 2011: 84)

During the mid-20th Century as the Human Relations movement emerged, there was an increased realization then the individual attention in positive form were required like to encourage them and consider their needs and moreover work was designed in a lenient way which leads to emphasis on allowing people scope within their work for social interaction, personal development, and the realization of their own ambitions (Garg and Rastogi, 2006).

Since then, there has been emerging trend of research which combines all the elements together so that the job design and employee satisfaction level enhanced, and on the other hand, maximize the productivity and performance of organizations on the other. We never deny the impact every individual does different work at a different level which has an impact on their involvement and efficiency if their work (Morgeson et al., 2011; Shantz et al., 2013). Other things which are very important like how jobs are inserted within their broader organizational contexts, how they interrelate with one another, and the design of the wider organization itself. To increase the level of employee's involvement job design must be matched with employee's needs (Grzywacz and Dooley, 2003).

However, job design still remains a concept that got less concentration from employer's and policymakers because both of them have an impact on employees involvement compared with other aspects of management such as leadership or management style (Truss, 2012).Far more jobs today are dead-ends compared to the situation in previous generations, which shortens the tools available to manage the workforce and control the hurdles in the progress of employee's development (Applebaum, Bernhardt, \&Murnane, 2003; Corak, 2004).

Although through job design literature we can understand the most of the organizations projecting more significant and autonomous work and the belief held that design them 
according to their comfort zone (e.g., Grant, Fried, \& Juillerat, 2009), it is not obvious how well this applies in retail.

For instance, when people find their work monotonous and unchallenging this can turn into the state of stress and employee's less involved because the human resources exhausted (Morgeson and Humphrey, 2006; Work Foundation, 2009). On the other hand, people interested to do challenging assignments and they feel enthusiastic and inspired to put all their efforts in the work and focus on organization growth and this is output of personal efforts that lies at the heart of engagement (Crawford et al., 2013)

With increasing trend of Human resource management, it has been proposed that are continuously struggling to maintain job analysis as a Human Resource Planning (HRP) strategy are likely to gain competitive advantage (Anthony et al., 2002; Dessler, 2003).

"In accordance with this definition, it is stated that a well-designed and defined job increase employees job satisfaction, increases motivation, decreases workplace-related stress, encourage learning efforts (Lantz and Brav, 2007, p. 270) and is, therefore, have a positive effect on employees' performance” (Garg and Rastogi, 2006, p. 575). “In a recent General Social Survey, Americans reported that important, meaningful work is the job feature they value most-above promotions, income, job security, and hours" (Cascio, 2003).

\section{RESEARCH METHODOLOGY}

Research Model

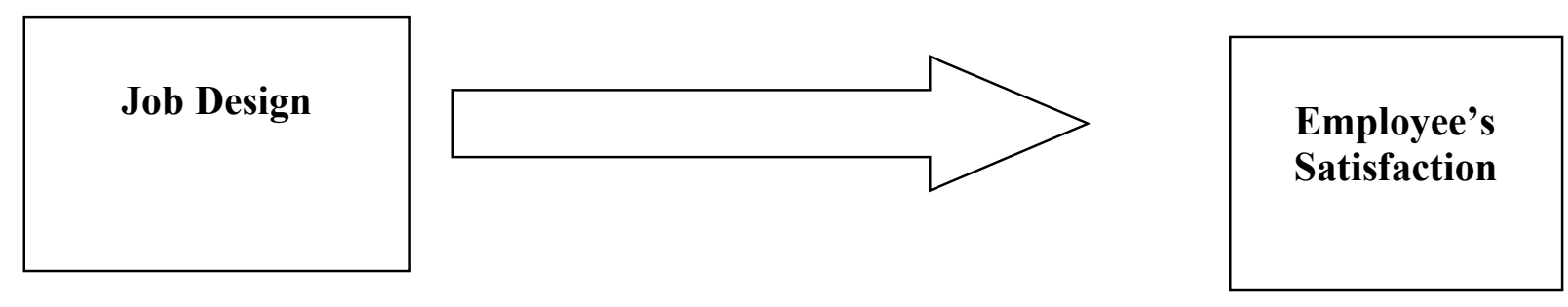

$>$ Motivation

$>$ Feedback

$>$ Healthy environment

$>$ Promotional activities

$>$ Teamwork

\section{Job design}

Nowadays the job design getting the attention of every employer and they considered this element as a broader perspective. Job design itself includes various dimensions such as promotional activities, motivation, timely feedback, comfortable environment, and teamwork etc. All these factors contribute and give proper understanding the attitudes of employees towards work. The proposed model recognizes certain characteristics that psychologically or physically affect the employees' traits.

The aim of this research is to identify the key issues that employees faced as a major threat and have adverse impacts on the betterment of the organization. The factors are discussing one by one below: 
Motivation

Motivation considered as one of the vital element that boosts up the morale of every individual. As an employer, you consider such intangible elements as a moral responsibility of every supervisor. Such factors give extra benefits to the organization and employees give proper value to the organization.

\section{Feedback}

The emerging demands of the work just because of sudden changes in performing the work patterns. To increase the productivity of the organization feedback must be given on time. The feedback has two aspects either positive or negative. Moreover, the positive feedback motivates employee to work efficiently and on the contrary the negative feedback given in such a way that employee takes it as positive and tried to cure such deficiencies.

\section{Promotional activities}

The employees satisfied only when they got the proper growing opportunities in the organization. If the employees get the proper exchange value then they definitely committed to their work. The organization provides a timely increase in salary or advancement in designation encourages the employees to stay in the organization.

\section{Teamwork}

Teamwork is a necessary element in every field that strong the idea generation and implements quick solutions. The contribution of players with positive states of mind strong the relationship among the members. Moreover, in job design, the employer considered the teamwork as the important constitute that indulges in the performance of every individual.

\section{Healthy Environment}

The job must be designed according to the requirements of the individual. The working conditions in the organization are quite suitable then the output will be huge. The working hours and targets increased stress on employees so, in return performance will be down.

\section{Employees satisfaction}

The factors discussed above directly trigger towards the employee's satisfaction. If organization give proper importance to these factors then conflicts resolve automatically. Moreover, the stage in which the employee feels secure in the organization then they do extra work without any personal benefits. The bottom line of this research to focus on those factors that create problems in the life of professors so, their attention diverted. This research helps to understand the clear link between the employees and top management policies.

\section{Hypothesis Formation \\ Hypothesis \\ Ho: Job design has no significant impact on employee's satisfaction level \\ H1: Job design has significant impact on employee's satisfaction level}

\section{Sample}

The population of interest in this study comprises of Teachers in private and public universities of Faisalabad. The educational sector is selected because this is one of emerging sector in the economy of Pakistan so, we collected data from public and private universities of Faisalabad by distributing questionnaires. The sample size was 100 and different statistical tools can be implemented on it. The convenient sampling method has been done to complete our research. 


\section{Introduction}

\section{DATA ANALYSIS AND INTERPRETATION}

The part of this research provides the complete overview of those areas which can be investigated in this study. Below the analyses and interpretation data has been shown for the understanding which presents the mixed reviews of the respondents. The data can be analyzed by applying descriptive statistical tools like reliability test, regression test etc. For the purpose of efficiency and accuracy, the 21 version of SPSS (Statistical package for social sciences) used to analyze the data and interpret the results.

\section{Reliability test}

Case Processing Summary

\begin{tabular}{|ll|r|r|}
\hline & & N & \multicolumn{1}{|c|}{ \% } \\
\hline Cases & Valid & 100 & 100.0 \\
& Excluded & 0 & .0 \\
& Total & 100 & 100.0 \\
\hline
\end{tabular}

a. Listwise deletion based on all variables in the procedure.

Reliability Statistics

\begin{tabular}{|c|c|}
\hline & \\
\hline Cronbach's Alpha & No. of Items \\
\hline .964 & 16 \\
\hline
\end{tabular}

\section{Cronbach's Alpha}

The internal reliability of the instrument was measured by Cronbach's alpha. The default value of 0.964 reliability and the results show that the device is reliable.

\section{Regression Analysis}

\section{Hypothesis}

Ho: Job design has no significant impact on employee's satisfaction level

H1: Job design has significant impact on employee's satisfaction level

Table 1

Variables Entered/Removed ${ }^{b}$

\begin{tabular}{|l|l|l|l|}
\hline Model & \multicolumn{1}{|c|}{$\begin{array}{c}\text { Variables } \\
\text { Entered }\end{array}$} & $\begin{array}{c}\text { Variables } \\
\text { Removed }\end{array}$ & Method \\
\hline 1 & jobdesign $^{\mathrm{a}}$ & & Enter \\
\hline
\end{tabular}

a. All requested variables entered.

b. Dependent Variable: Employee satisfaction 
Table 2

Model Summary

\begin{tabular}{|c|c|c|c|c|}
\hline Model & R & R Square & Adjusted R Square & $\begin{array}{c}\text { Std. Error of the } \\
\text { Estimate }\end{array}$ \\
\hline 1 & $.890^{\mathrm{a}}$ & .792 & .790 & .43194 \\
\hline
\end{tabular}

a. Predictors: (Constant), job design

\section{Interpretation}

Correlation between Job design and employee's satisfaction is .890 i.e. 89\% which indicates the strong relationship between these two variables. A value of $\mathbf{R}$ square is .792 which indicates that $79.2 \%$ of the variability in the dependent variable (Employee's satisfaction) is explained by its linear relationship with the independent variable (Job design) and the remaining variation $20.8 \%$ is due to chance or other factors.

Table 3

ANOVA $^{\mathrm{b}}$

\begin{tabular}{|ll|r|r|r|r|r|}
\hline Model & Sum of Squares & Df & Mean Square & \multicolumn{1}{c|}{ F } & Sig. \\
\hline 1 & Regression & 69.489 & 1 & 69.489 & 372.456 & $.000^{\mathrm{a}}$ \\
& Residual & 18.284 & 98 & .187 & & \\
& Total & 87.772 & 99 & & & \\
\hline
\end{tabular}

a. Predictors: (Constant), job design

b. Dependent Variable: Employee satisfaction

\section{Interpretation}

Since the P-value falls in the critical region because P-value is less than the Critical value i.e. $\alpha=0.05$. So we reject our null hypothesis which means that Job design has a significant impact on employee's satisfaction level.

Table 4

Coefficients ${ }^{\mathrm{a}}$

\begin{tabular}{|c|c|c|c|c|c|c|}
\hline \multirow{2}{*}{\multicolumn{2}{|c|}{ Model }} & \multicolumn{2}{|c|}{ Unstandardized Coefficients } & \multirow{2}{*}{$\begin{array}{c}\begin{array}{c}\text { Standardized } \\
\text { Coefficients }\end{array} \\
\text { Beta }\end{array}$} & \multirow[b]{2}{*}{$\mathbf{T}$} & \multirow[b]{2}{*}{ Sig. } \\
\hline & & B & Std. Error & & & \\
\hline \multirow[t]{2}{*}{1} & (Constant) & .366 & .163 & & 2.245 & .027 \\
\hline & Job design & 1.062 & .055 & .890 & 19.299 & .000 \\
\hline
\end{tabular}

a. Dependent Variable: Employee satisfaction

\section{Interpretation}

Fitted regression model employee's satisfaction with job design is:

\section{Employees satisfaction $=.366+1.062 \mathrm{Job}$ design}

(OR)

$$
Y=.366+1.062 X
$$

$\mathrm{Y}$ intercept $=.366$ indicates that If job design variable ignores from the study then on the average Employees satisfaction level is .366 and slope coefficient $=1.062$ shows that if we 
increased one unit in $\mathrm{X}$ (Job design) then on the average expected a change in $\mathrm{Y}$ (Employees satisfaction) will be 1.062 .

\section{CONCLUSION}

Job design is itself a broader term for the determinant of employee's satisfaction in case of public and private universities. In addition, more variables were indulged in this study such as motivation, feedback, healthy environment, teamwork and promotional activities etc. in understanding the broader context of Job design. According to the results of this research shows that the above-mentioned variables have a significant impact which depicts that all studied factors never be neglected at any cost. Moreover, the value of $\mathbf{R}$ square in the ANOVA table depicts the $79.2 \%$ of the factors have strongly described the study and remaining percentage which 20.8\% represents the chances of other factors indulged in this research. Correlation (R) between Job design and employee's satisfaction was positive .890 i.e. 89\% which indicates the strong relationship between these two variables.

Undoubtedly the job design is relevant to the productivity and performance of the employee's. The long-term survival of any organization possible only if they treat all the factors on an equal basis that impede the growth. In short, the job design itself is not the major determinant of employee's satisfaction other extraneous factors involved in the research that directly or indirectly link with job design.

\section{FUTURE DIRECTIONS}

Based on the study conducted and for that matter the results obtained, the following recommendations were made in order to improve organizational productivity and increase the satisfaction level of employees in Pakistan.

1. Jobs in the organization should be designed according to the requirements of individuals that increase the performance level of employees.

2. Organization considered job design as a vital element because in the absence of this the organization faced adverse effects

3. Despite the achievements of this research it will pursue the attention of other researchers to search in this field and find more ways to protect the both employee's and employer's

\section{ACKNOWLEDGEMENT}

As a first author, my deep appreciation goes to Muhammad Rashid Yousaf (Lecturer), School of Business Management, NFC Institute of Engineering and Fertilizer Research, Pakistan for his Constant help, guidance and countless attention. We would also like to pay thanks to School of Management \& Economics, University of Electronic Science and Technology of China (UESTC) for projecting a research environment. Lastly special thanks to all the employees from Pakistan who projected their valuable review through a questionnaire.

\section{References}

Adebakin MA, Ogundele OJ, Sulaimon AA (2008), Effect of job satisfaction and organisational commitment on organisational citizenship behavior. Proceedings of African Regional Conference

Al-Ahmadi, H., (2009), Factors Affecting Performance of Hospital Nurses in Riyadh Region, Saudi Arabia. International Journal of Health Care Quality Assurance, 22 (1), 40-54

Anthony, W.P., Kacmar, K.M., \&Perrewe, P.L. (2002). Human Resource Management: A Strategic approach

Andy N, Mohammend AN (2006). "The True Role of Performance Measurement California Journal of Management Review Vol. 48, No.3. University of California, Berkeley 
Anseel, F, and Lievens, F (2007). The long -term impact of the feedback environment on job satisfaction: A field study in a Belgian context. Applied Psychology: An International Review, http://www.google.com

Applebaum, E., Bernhardt, A. D. \&Murnane, R. J. (Eds.). (2003). Low-wage America: How employers are reshaping opportunity in the workplace. New York: Russell Sage.

Bahram Alishiri. (2012)." A New Optimal Model of job design and Characteristics for Governmental Banks; Global Approach" International Conference on Economics, Business and Marketing Management, IPEDR vol.29 (2012) (C) (2012) IACSIT Press, Singapore

Bakker, A.B., and Salanova, M. (2006). The measurement of work engagement with short questionnaire: a crossnational study, Educational and Psychological Measurement,66, 701-16,

Brannick, M. T., Levine, E. L., \& Morgeson, F. P. (2007). Job analysis: Methods, research, and applications for human resource management ( $2^{\text {nd }}$ Ed.). Thousand Oaks, CA: Sage Publications

Brewer GA, Lee (2005) "Federal Agencies in Transition: Assessing the impact on Federal Employees job satisfaction and performance

Campion, et al, (2005), Work Redesign: Eight Obstacles and Opportunities. Human Resource Management, 44(4), 367-390.

Cascio, W. F. 2003. Changes in workers, work, and organizations. In W. Borman, R. Klimoski, \& D. Ilgen (Eds.), Handbook of psychology. Volume 12: Industrial and organizational psychology: 401-422. New York: Wiley.

Christian, M.S., Garza, A.S., and Slaughter, J.E. (2011), work engagement: a quantitative review and test of its relations with task and contextual performance, Personnel Psychology, 64, 89-136.

Corak, M. (Ed.). (2004). Generational income mobility in North America and Europe. Cambridge UK: Cambridge University Press

Corpanzano, R. (2010), from thought to action: employee work engagement and job performance, In A, B, Bakker, and M, P, Leiter (eds), Work engagement: A handbook of essential theory and research (pp, 147-63), New York: Psychology Press

Crawford, E., Rich, B., Buckman, B. and Bergeron, J. (2013 - in press) 'The Antecedents and Drivers of Employee Engagement', in Truss, C., Alfes, K., Delbridge, R., Shantz, A. and Soane, E. (Eds) Employee Engagement in Theory and Practice. London: Routledge.

Demerouti, E., Bakker, A.B., Nachreiner, F., and Schaufeli, W.B, (2001), The job demands-resources model of burnout, Journal of Applied Psycholgy, 86, 499-512.

Dessler, G. (2003) Human Resource Management, 9th ed. Englewood Cliffs, NJ: Prentice Hall.

Garg, P. and Rastogi, R. (2006) 'New Model of Job Design: Motivating Employees' Performance', Journal of Management Development, Vol. 25, No. 6, pp. 572-587.

Grant, A. M., Fried, Y., \& Juillerat, T. (2009). Work matters: Job design in classic and contemporary perspectives. In S. Zedeck (Ed.), APA handbook of industrial and organizational psychology. Washington, DC: American Psychological Association

Grzywacz, J. and Dooley, D. (2003) 'Good Jobs to Bad Jobs: Replicated Evidence of an Employment Continuum from Two Large Surveys', Social Science \& Medicine, Vol. 56, No.8, pp. 1749-60.

Harter, J.K., Schmidt, F. L., and Hayes, T. L. (2002), Business-unit-level relationships between employee satisfaction, employee engagement, and business outcomes: A meta-analysis, Journal of Applied Psychology, 87, 268-79.

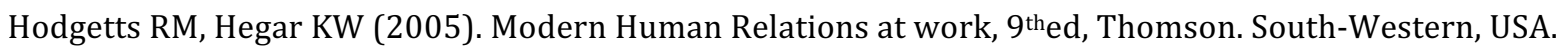

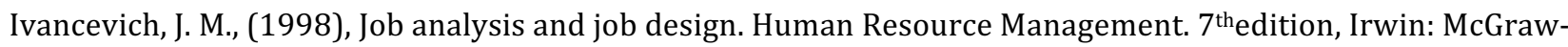
HILL., pp.168-195.

Judge TA, Parker S, Colvert AE, Heller D, Ilies R (2001). “Job Satisfaction: A cross- cultural review”. In N. Anderson, D. S. Ones, H. K. Sinangil and C Viswesvaran, eds. Handbook of Industrial, Work and Organizational Psychology. (2) 25 - 52. London; Sage

Kreitner R, kinicki A (2001) Organizational Behaviour, $5^{\text {th }}$ Ed. Boston, MA: McGraw - Hill

Lantz, A. \&Brav, A. (2007). Job design for learning in work groups. Journal of Workplace Learning, 19(5), $269-285$.

Mathis, R.L., \& Jackson, J. H., (2003), Individual Performance and Retention. Human Resource Management. Thomson Publication. 10th Edition, pp.66-99. 
Mehta, V. \& Shah, H., (2005), Characteristics of a Work Organization from a Lean Perspective. Engineering Management Journal. 17(2), 14-20.

Morgeson, F. P., and Humphrey, S. E. (2006) 'The Work Design Questionnaire (Wdq): Developing and Validating a Comprehensive Measure for Assessing Job Design and the Nature of Work,' Journal of Applied Psychology, Vol. 91, pp. 1321-1339.

Morgeson, F., Dierdorff, E. and Hmurovic, J. (2010) 'Work Design in situ: Understanding the Role of Occupational and Organizational Context', Journal of Organizational Behavior, Vol. 31, pp. 351-360.

Oldham, G. R. (1996). Job design. International Review of Industrial and Organizational Psychology, 11, 33-60 Opatha, H.H.D.N.P., (2002), Performance Evaluation of Human Resource. 1st Edition, pp.2-12,170-183, Colombo, Sri Lanka: The Author publication.

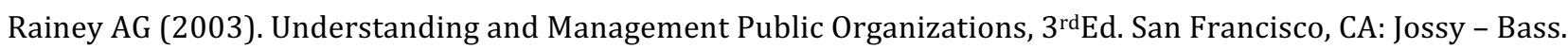

Robbins, Stephen P. and Robin Stuart-Kotze. (c1986). Management: Concept and Practices. Canadian Edition. Toronto: Prentice-Hall.

Schaufeli, W.B., Bakker, A. B, (2004), job demands, job resources and their relationships with burnout and engagement: a multi-sample study, Journal of organizational behavior,25, 293-315.

Shantz, A., Alfes, K., Soane, E., and Truss C. (2013 - in press) 'A Theoretical and Empirical Extension of the Job Characteristics Model'. International Journal of Human Resource Management.

Sinha, K.K. \&Ven, A. H., (2005), Designing Work Within and Between Organizations. Organization Science. 16(4), 389-410.

Spector PE (1997) Job Satisfaction. Thousand Oaks, CA: Sage

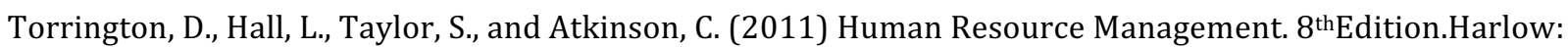
Pearson.

Truss, C. (2012) 'Spinning Plates and Juggling Hats: Employee Engagement in an Era of Austerity'. Wimbledon: CIPD.

Ugboro, I.O. (2006), Organizational Commitment, Job Redesign, Employee Empowerment and Intent to Quit Among Survivors of Restructuring and Downsizing. Journal of Behavioural and Applied Management, 7(3), 232-254.

Work Foundation (2009) Knowledge Workers and Knowledge Work. A Knowledge Economy Programme Report. Lancaster: Work Foundation. 